\title{
IMPACT OF SOCIAL MEDIA USAGE ON ACADEMIC PERFORMANCE OF TERTIARY INSTITUTION STUDENTS: EVIDENCE FROM ACCRA \& TEMA METROPOLIS, GHANA.
}

\author{
Edward Asante ${ }^{1 *}$, Edward Markwei Martey ${ }^{2}$ \\ *1Library Department, Koforidua Polytechnic, P.O.Box KF 981, Koforidua, Ghana \\ ${ }^{2}$ Marketing Department, Koforidua Polytechnic, P.O.Box KF 981 Koforidua, Ghana \\ *1Email: eddieasante59@gmail.com, ${ }^{2}$ edmarkwei@yahoo.com
}

*Corresponding Author: -

Email: eddieasante59@gmail.com.

\begin{abstract}
: -
The study sought to assess the relationship between student's use of social media and academic performance of tertiary institutions students in Ghana with a focus on Accra and Tema Metropolis. Questionnaire was used for collecting data. Out of one thousand copies of the questionnaire distributed, a valid response of $70.0 \%$ was retrieved. SPSS computer software was used to measure descriptive, correlation, regression among others. The study revealed that all the constructs of social media (dependent variable) had a significant positive relationship thus the independent variables (Facebook, Whatsapps, Yahoo Messenger, Skype, and Twitter) at level with the dependent variable academic performance.
\end{abstract}

Keywords: - Social Networks, Academic Output, Tertiary Students, Internet Use, West Africa.

\section{(c) (\$) (1)}




\section{INTRODUCTION}

According to Asur and Huberman, (2010) social media has exploded as a category of online discourse where people create content, share it, bookmark it and network at a prodigious rate. Because of its ease of use, speed and reach, social media is fast changing the public discourse in society and setting trends and agenda in topics that range from the environment and politics to technology and the entertainment industry. Oberst, (2010) posits that, in the last ten years, the online world has changed dramatically, thanks to the invention of social media, young men and women now exchange ideas, feelings, personal information, pictures and videos at a truly astonishing rate. Seventy-three percent of wired American teens now use social media websites.

Boyd (2007) draws attention that, the increased use of social networking websites has become an international phenomenon in the past several years. What started out as a hobby for some computer literates has become a social norm and way of life for people from all over the world Teenagers and young adults have especially embraced these sites as a way to connect with their peers, share information, reinvent their personalities, and showcase their social lives. Schneider (2009) found out that, in the past years, social media websites have become common thus giving young people a new way to interact with each other and communicate with the world. Social networking became popular between 2004 and 2006, after Facebook and MySpace were created. Facebook, for example has over 500 million members and it is still growing and approximately $85 \%$ of undergraduate students are Facebook users.

Schneider (2009) added that, these numbers are expected to grow since social media users such as Facebook, Twitter, MySpace, Yahoo Messenger, will continue to grow. And this is not only true for the afro-mentioned but for YouTube users closely follow as well. According to Asur and Huberman (2010) social networking websites provide tools by which people can communicate, share information, and create new relationships. With the popularity of social networking websites on the rise, our social interaction is affected in multiple ways as we adapt to our increasingly technological world. The way web users interact and talk to each other has changed and continues to change. These users now socialize through the internet and it takes away from the person socialization that has been around forever. Social networking websites have affected our social interaction by changing the way we interact face-to-face, how we receive information, and the dynamics of our social groups and friendships.

Kaitlin (2010) commenting on social media stress that, internet and social networking websites is quite different from communicating in- person- to- person situation. When users communicate through these websites, they use things like instant message (IM) and chatting as well as status or Twitter updates to talk to friends and express themselves. Kaitlin (2010) further opines that social networking websites also affect the way we receive information and news. The sites open up different portals through which we get information and create more diverse news outlets.

Most of the studies, Choney (2010), San Miguel, (2009) Enriquez (2010), Karpinski \& Duberstein (2009), Khan, (2009), Kubey et al (2010), conducted on students' use of the social media and its impact on academic performance focused on students in the developed world. It is against this background that it has become necessary to conduct this research aimed at investigating the relationship between students' use of social media and their impact on academic performance of tertiary students in Ghana. This is largely because the researchers have not come across any empirical study on the relationship between students' use of social media and their impact on academic performance of tertiary conducted in Ghana.

\section{Objectives of the Study}

The general objective of the study was to find out the impact of social media on academic performance among tertiary students in Ghana. The specific objectives of the study were as follows:

i. To examine the association between Facebook and academic performance among the students.

ii. To assess the correlation between Whatsapps and academic performance among the students.

iii. To evaluate the relationship between Skype and academic performance among the students.

iv. To evaluate the association between Yahoo messenger and academic performance among the students.

v. To evaluate the association between Twitter messenger and academic performance among the students.

\section{Literature Review \\ Definition of social media}

Martin (2008) and Lusk (2010) defined social media as an aspect of the Internet which allows individuals and groups to create and publish online content, share the content, and interact about it through the use of Facebook, Skype, Blogs, MySpace, LinkedIn, Yahoo Messenger, Whatsapps and Twitter. The study simplifies social media as a platform on the internet where young and old generations meet to communicate, share ideas and develop friendship by use of Facebook, Skype, Blogs, MySpace, LinkedIn, Yahoo Messenger, Whatsapps and Twitter.

\section{Facebook}

Schneider (2009) indicated in a previous study that Facebook, for example has over 500 million members and it is still growing and approximately $85 \%$ of undergraduate students are Facebook users. According to a study conducted in University of New Hampshire (2009) these numbers are expected to grow since Facebook users will continue to grow. And this is not only true for Facebook; numbers for YouTube users closely follow as well. San Miguel (2009), focused on the relationship between time spent on Facebook and the academic performance of students. The overall findings indicated "more time on Facebook equals slightly lower grades". In his study, the average Facebook user had a GPA of 3.0 to 3.5, while the non-Facebook user had a GPA of $3.5-4.0$. Also, the average Facebook user study for $1-5$ hours per week, while the non-Facebook user would study 11 - 15 hours per week. 
In a study by Pempek, Yermolayeva, and Calvert (2009), the amount of time spent daily on social network sites varied greatly. However, an analysis of the data indicated most participants spent approximately thirty minutes a day socializing, mostly during the evening hours between 9p.m to 12a.m students spent an average of forty-seven minutes a day on Facebook. More than $50 \%$ of college students go on a social networking site several times a day (Sheldon, 2008). Quan-Haase and Young (2010), found that $82 \%$ of college students reported logging into Facebook several times a day. Younger students tended to use Facebook more frequently than older students to keep in touch with friends from high school or from their hometown (Pempek et al., 2009).

\section{Skype}

According to Khan (2009), Skype users often time experience poor performance academically. Similarly, Englander et al., (2010), posit that social media is negatively associated with academic performance of student and is a lot more momentous than its advantages.

\section{Yahoo Messenger}

Kist (2008) found out that approximately ninety percent of teens in the United States have Internet access, and about seventy-five percent of these teens use the Internet more than once per day This study also showed that approximately half of all teens who have Internet access are also members of social networking sites like Yahoo Messenger, and use the Internet to make plans and socialize with friends.

\section{Whatsapps}

According to Lenhart et al., (2010), about 57\% of Whatsapps users are 18-29 years old and have a personal profile on multiple social media websites too.

\section{Twitter}

Choney (2010), looking at the time spend on Twitter and its effect on academic performance concluded that a user of Twitter has an average GPA of 3.06, while non users have an average GPA of 3.82.

\section{The Relationship between social media and Academic Performance}

Many researchers such as Choney (2010), San Miguel (2009) and Enriquez (2010) studies on students' use of the social media revealed a negative effect of the use of social media on students' academic performance. The American Educational Research Association conducted research and declared at its annual conference in San Diego California (2009), that social media users' study less and generate lower grades (Abaleta et al, 2014). Furthermore, a study conducted by Karpinski and Duberstein (2009), of Ohio Dominican university on college students who use social network have significantly lower grade point averages (GPAs) than those who do not. Jocabsen and Forste (2011), found a negative relationship between the use of various media, including mobile phones, and self-reported GPA among first year university students in the United States.

In Taiwan, Yen at el. (2009) identified an association between mobile phone use and respondents and report that respondents have allowed phone use to interfere academic activities whether or not they have allowed phone use to interfere with important social, academic and recreational activities during the previous year. A study conducted at Whittemore school of Business and Economic on one thousand, one hundred and twenty-seven students concluded that there is no correlation between how much time is spent on social networking and grades (Martin, 2009) However, other studies like Ahmed and Qazi (2011), Hanqittai and Hsich (2010), Pasek and Hanqittai (2009), conducted on the same topic exposed no correlation between social media and students' academic performance. Again, University of New Hampshire (2010) study also revealed that students' use of social media sites does not affect grades.

\section{Figure 1: Research Frame Work}

Variables of social media

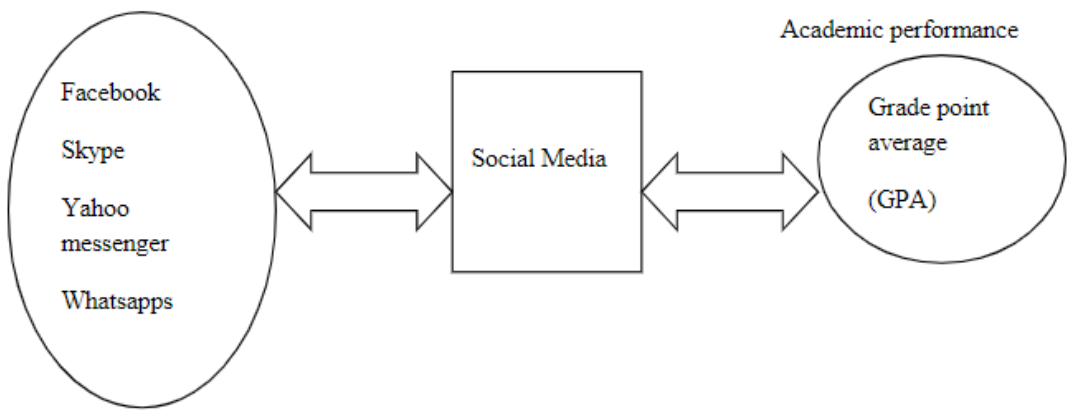

Source: Authors construct (2014).

\section{Research Hypotheses}

i. There is a significant relationship between Facebook and academic performance among the students.

ii. There is a significant relationship between Whatsapps and academic performance among the students.

iii. There is a significant relationship between Skype and academic performance among the students.

iv. There is a significant relationship between Yahoo messenger and academic performance among the students. 
v. There is a significant relationship between Twitter and academic performance among the students.

\section{Statement of Problem}

The rapid advancement of media technology has had a great impact on the way people communicate on a daily basis. The growing dimension of the use of the social media among the youth of today cannot be over emphasized. Over the years, social networking among students has become more and more popular. It is a way to make connections, not only on campus but with friends outside of school. Social networking is a way that helps people to feel, they belong to a community. Due to the increased popularly of it, economists and professors are questioning whether grades of students will not be affected by how much time is spent on these sites. Choney, (2010), MehMood \& Taswir, (2013), Kist (2008), Jacobsen \& Forste, (2011), believe that the use of technology such as internet is one of the most important factors that can influence educational performance of students positively or adversely. Many parents and guardians are worried that students are spending too much time on Facebook, Twitter, Skype, Yahoo Messenger and other social media sites. Though parents are worried about students' constant use of the social media sites, many students are becoming addicted to the utilization of these sites on a daily basis. It is against this backdrop that this research is being conducted to ascertain the impact of students' use of social media sites on academic performance.

\section{Methodology}

The survey was a cross sectional descriptive study with the use of questionnaire as the main instrument for data collection. The study was mainly a quantitative approach to solve the study problem.

\section{Population}

The targeted population of the study was tertiary students between the ages of 18 - 30 years, both sexes, residents of Tema and Accra metropolis who have been on social media for at least one year.

\section{Sampling}

Probability Simple random sampling technique was adopted to distribute the questionnaire to the respondents in Tema and Accra metropolis. This was employed in other to give every respondent an equal chance of been part of the study. Out of one thousand (1000) questionnaires distributed, seven hundred and thirty three (733) were returned but after editing and sorting, seven hundred and one (701) was found valid for analysis and interpretation and constitute $70 \%$ of the sample size.

\section{Data collection}

Data were collected through the use of a questionnaire. The questionnaire was divided into three sections. Section A elicited general and biographical information about respondents. Section B elicited information on respondent's use of Facebook, Skype, Yahoo Messenger, Whatsapps and Twitter and section C elicited information on respondent's academic performance. The questionnaire consisted of 21 items covering the variables.

\section{Data Analysis}

Statistical Package for Social Science (SPSS) was employed to determine, descriptive, correlation, regression among others.A

\section{Table 1: Demographic information}

\begin{tabular}{lll}
\hline Participants & Frequency $(\mathrm{N}=566)$ & Percentage (\%) \\
\hline Accra & 456 & 65.05 \\
Tema & 245 & 34.95 \\
Gender & & \\
Male & 345 & 49.22 \\
Female & 356 & 50.78 \\
\hline
\end{tabular}

Source: Survey Data, 2013

Results from Table 1, indicate that $65.05 \%$ of respondent were from Accra and the rest $34.95 \%$ also were from Tema Metropolis. In addition, $49.22 \%$ of the respondents were Male and $50.78 \%$ were Female.

Table 2: Model Summary

\begin{tabular}{|c|c|c|c|c|}
\hline Model & $\mathrm{R}$ & $\mathrm{R}$ Square & Adjusted R Square & $\begin{array}{c}\text { Std. Error of the } \\
\text { Estimate }\end{array}$ \\
\hline 1 & $867^{\mathrm{a}}$ & .845 & .894 & .27634 \\
\hline
\end{tabular}

a. Predictors: (Constant), facebook, Twitter, Skype, Yahoo messenger, Whatsapps.

The results of the multiple regression analysis, as shown in Table 2, $\mathrm{R}$ determines the correlation between social media construct and academic performance. The correlation between the two variables is 0.867 which explains a strong positive significant relationship. Coefficient of determination, $\mathrm{R}^{2}$, predicts the relationship between the independent variables and dependent is 0.845 . This means that 84 percent of the total variance in the dependent variable (Academic 
Performance) is accounted for by the independent variables (Facebook, Twitter, Skype, Yahoo Messenger and Whatsapps). This result affirms that all the five constructs of social media is significant in affecting academic performance. This indicates that more time spent on social media translate into poor academic performance.

Table 3: Anova ${ }^{a}$

\begin{tabular}{|c|c|c|c|c|c|c|}
\hline & Model & Sum of Squares & Df & Mean Square & $\mathrm{F}$ & Sig. \\
\hline 1 & $\begin{array}{c}\text { Regression } \\
\text { Residual } \\
\text { Total }\end{array}$ & $\begin{array}{l}37.155 \\
46.465 \\
83.620\end{array}$ & $\begin{array}{c}5 \\
44 \\
49\end{array}$ & $\begin{array}{l}7.431 \\
1.056\end{array}$ & 7.037 & $.000^{\mathrm{b}}$ \\
\hline
\end{tabular}

a. Dependent Variable: academic performance

b. Predictors: (Constant), facebook, Twitter, Skype, Yahoo messanger, Whatsapp

The results of the F-ratio, as shown in Table 3, indicates that the regression model is significant at $\mathrm{p}<0.001$. It can be concluded, that the regression model predicts reading habits strongly. In other words, the social media construct: Facebook, Twitter, Skype, Yahoo Messenger, Whatsapp (the independent variables) have the ability to predict Academic Performance (the dependent variable).

Table 4: Coefficients ${ }^{\mathrm{a}}$

\begin{tabular}{|c|c|c|c|c|c|c|}
\hline \multirow{2}{*}{\multicolumn{2}{|c|}{ Model }} & \multicolumn{2}{|c|}{$\begin{array}{l}\text { Unstandardized } \\
\text { Coefficients }\end{array}$} & \multirow{2}{*}{$\begin{array}{c}\begin{array}{c}\text { Standardized } \\
\text { Coefficients }\end{array} \\
\text { Beta }\end{array}$} & \multirow[t]{2}{*}{$\mathrm{t}$} & \multirow[t]{2}{*}{ Sig. } \\
\hline & & $\mathrm{B}$ & Std. Error & & & \\
\hline \multirow{6}{*}{1} & (Constant) & 5.752 & .981 & & .412 & .000 \\
\hline & Skype & -.083 & .215 & 425 & 3.36 & 000 \\
\hline & Twitter & -.197 & .214 & 415 & 4.60 & 000 \\
\hline & $\begin{array}{l}\text { Yahoo } \\
\text { messanger }\end{array}$ & .040 & .027 & 475 & 3.95 & 000 \\
\hline & Whatsapp & .705 & .368 & 412 & 4.60 & 000 \\
\hline & Facebook & -1.454 & 385 & 430 & 4.05 & .000 \\
\hline
\end{tabular}

a. Dependent Variable: academic performance

The regression analysis presented in Table 4 indicates that Academic Performance determined by the social media construct of Facebook, Skype, Twitter, Yahoo messenger and Whatsapps. Skype has a beta value of

0.425. This means that Skype explains $42.5 \%$ of Academic Performance, at a p-value of 0.000. This explains a significant positive association of Skype with Academic Performance. Twitter has a beta value of .415. This means that Twitter explains $41.5 \%$ of Academic Performance, at a p-value of 0.000 . This indicates a significant positive association of Twitter with Academic Performance.

Yahoo Messenger has a beta value of 0.475. This means that Yahoo messenger explains $47.5 \%$ of Academic Performance, at a p-value of 0.000. This shows a significant relationship between o Yahoo messenger and Academic Performance. Whatsapps has a beta value of 0.412 . This means that Whatsapps explain $41.2 \%$ of Academic Performance, at a p-value of 0.000 . This shows a significant relationship between of Whatsapps and Academic Performance. Facebook has a beta value of 0.430. This means that Facebook explains $43.1 \%$ of Academic Performance, at a p-value of 0.000. This shows a significant relationship between of Facebook and Academic Performance. Regression model is significant at $\mathrm{p}<0.005$. The above data shows that all the above hypothesized relationships between social media and Academic Performance are accepted.

Table 5: Summary of research hypotheses and results

\begin{tabular}{|l|l|l|l|l|}
\hline Hypotheses & Description & Beta & $\mathbf{t}$-value & Comment \\
\hline H1 & $\begin{array}{l}\text { There is a significant relationship between Skype and academic } \\
\text { performance among the students. }\end{array}$ & 0.425 & 3.36 & Accepted \\
\hline H2 & $\begin{array}{l}\text { There is a significant relationship between Twitter and academic } \\
\text { performance among the students. }\end{array}$ & 0.415 & 4.60 & Accepted \\
\hline H3 & $\begin{array}{l}\text { There is a significant relationship between Yahoo messenger and } \\
\text { academic performance among the students. }\end{array}$ & 0.475 & 3.95 & Accepted \\
\hline H4 & $\begin{array}{l}\text { There is a significant relationship between Whatsapps and } \\
\text { academic performance among the students. }\end{array}$ & 0.412 & 4.60 & Accepted \\
\hline H5 & $\begin{array}{l}\text { There is a significant relationship between Facebook and academic } \\
\text { performance among the students. }\end{array}$ & 0.430 & 4.05 & Accepted \\
\hline
\end{tabular}

\section{Discussion}

Kuppuswamy and Narayan (2010), argues that social networking websites distract students from their studies, but these websites can be useful for education based on sound pedagogical principles and proper supervision by the teachers. Moreover, the research concludes that social networking websites have both positive as well as negative impact on the education of youth, depending on one's interest to use it in a positive manner for his or her education and vice versa. 
A'lamElhuda and Dimetry (2014) explained that there is a prevalence of negative effect of using the social networks on academic performance and is high. Rithika and Sara (2013) added that using social media reduces students focus on learning and retaining information. Kuppuswamy and Shankar (2010) explained, social networks grab the total attention and concentration of the students and diverts it towards non educational, unethical and inappropriate actions such as useless chatting, time killing by random searching and not doing their jobs.

Shah et al. (2001) posits that the impact of social network on academic performance is determined by type of internet usage. Student are positively affected by the informative use of the internet whiles experience negative impact of recreation use of the internet. Also, Oskouei (2010) concluded that social network has positive impact on academic performance on both students and teachers if used as a tool of knowledge creation and dissemination. The effect depends on the type of social network student uses, if it is for leisure activity that disrupt or interferes with academic work, would affect the student academic performance negatively.

A study found out that using a social networking site while studying or doing homework could lower a student's grade. The study commented that "the problem is that most people have Face book or other social networking sites, their emails and maybe instant messaging constantly running in the background while they are carrying out their tasks" (Enriquez, 2010). Annual conference in San Diego, California (2009) organized by American Educational Research Association revealed that that social network users' study less and generated lower grades eventually.

Banquil et al. (2009) found a continuing drop of grades among student users of social networking sites. However, many researchers also found a positive association between use of internet and social networks and academic performance of the student users. Students, using internet frequently, scored higher on reading skills test and had higher grades as well (Linda et al., 2006)

According Kuppuswamy (2010) Social networking websites such as, Facebook, Myspace and Youtube are popular and have become part of daily life for an increasing number of people. The study argues that these social networking websites distract students from their studies. He concluded that social networking websites have both positive as well as negative impact on the education of youth, depending on one's interest of use. Social network media is beneficial to students as it opens up communication between students and teachers (Annetta et al., 2009; Heafner \& Friedman, 2008; Hrastinski, 2009; Jackson, 2011; Liu et al., 2011; Tomai et al., 2010).

Social media facilitates discussion and knowledge transfer among students through transfer of knowledge of course material (Carini et al., 2006; Chen \& Bryer, 2012; Fewkes \& McCabe, 2012; Garrett, 2011; Heafner \& Friedman, 2008; Kuh, 1993; Mazman \& Usluel, 2010; Shoshani \& Rose Braun, 2007; Yu et al., 2010). Thus, students who use social media are able to create new ideas that facilitate learning (Frye et al., 2010; Lamb \& Johnson, 2010). The use of social media can aid in the achievement of both general and content specific student learning outcomes (Carini et al., 2006; Junco, 2012b; Junco et al., 2011).

\section{Conclusion}

The study was conducted to examine the relationship between students' use of social media sites on their academic performance. In addition, the study revealed that the use of social media sites had affected academic performance of the respondents negatively and further confirmed that there was a positive significant relationship between the use of social media sites and academic performance at 0.001 level. The study further indicates that all the independent variables (Facebook, Whatsapps, Yahoo Messenger, Skype, and Twitter) had positive interrelationship with each other at level 0.01 .

\section{Recommendations}

Based on the findings, the researchers made some recommendations as follows;

Students with phones having internet facility should be encouraged to either use it to supplement their research in the library rather than the usual chatting with friends all the time. Students should be advised to limit the time they spend on social media sites per day and encourage them to rather substitute those hours to read novels and relevant academic books to improve their knowledge.

Since the study confirmed that the use of social media sites had affected the academic performance of students negatively, there is the urgent need for the introduction of students to the availability of novels and other information resource or materials in the library that can help them academically. It is further recommended that students be advice during orientation of the dangers of addiction to social networking sites. They should be introduced to site that can add values to their academic work and research.

\section{References}

[1].Abaleta, A. B, Centaza, S.M, \& Calimlim, M. E. (2004). Impact of Social Networking on the Academic Performance of College Students in Anellano University-(Unpublished Dissertation) pp. 1-19

[2].Ahmed, I. \& Qazi, T. (2011). A Look Out for Academic Impacts of Social Networking Sites (SNSs): A Student Based Perspective. African Journal of Business Management, 5(12), pp. 5022-5031.

[3].A'lamElhuda . D and Dimetry.A2014) The Impact of Facebook and Others Social Networks Usage on Academic Performance and Social Life among Medical Students at Khartoum University International Journal of Scientific \& Technology Research volume 3, issue 5,

[4].Annetta, L. A., Minogue, J., Holmes, S. Y., \& Cheng, M. T. (2009). Investigating the Impact of Video Games on High School Students' Engagement and Learning about genetics. Computers \& Education, 53, 74-85. doi: 10.1016/j.compedu.2008.12.020 
[5].Asur, S. \& Huberman, B.A. (2010) Predicting the Future with Social Media. Social Computing Lab: HP Labs, Palo Alto, California. pp 1- 8.

[6].Boyd, D.(2010) Taken Out of Context: American Teen Sociality in Networked Publics Berkeley,

[7].CA:Uniiversity of California; 2008. Available at: www.danah.org/papers/TakenOutOfContext.pdf. Accessed July 16, 2010

[8].Carini, R. M., Kuh, G. D., \& Klein, S. P. (2006). Student Engagement and Student Learning: Testing the Linkages. Research in Higher Education, 47(1), 1-32. doi: 10.1007/s11162- 005-8150-9

[9].Choney, S. (2010) Facebook Use Can Lower Grades by 20 Percent, Study Says.

[10]. http://www.msnbc.com/id/39038581/ns.technology and science-tech and gadgets/.Retrieved 14/08/13

[11]. Chen, B., \& Bryer, T. (2012). Investigating Instructional Strategies for Using Social Media in Formal and Informal Learning. International Review of Research in Open and Distance

[12]. Learning, 13(1), 87-104. Retrieved from http://www.irrodl.org/index.php/irrodl/article/view/1027/2073

[13]. Enriquez, J.G. (2010) Facebook and Other Online Social Networking Sites Can Lower Grades,

[14]. Study Says. http://seerpress.com/facebook-and-other-online-social-networking-sites-can- lower-grades-studysays/6935/.Retrived 14/08/1

[15]. Enriquez, J. (2010). Facebook and Other Online Social Networking Sites Can Lower Grades, Study Says

[16].. Retrieved from http://seerpress.com/facebook-and-other-online-social-networking-sites-can-

[17]. lower-gradesstudy-says/6935/.

[18]. Englander, F., Terregrosa, R. \& Wang, Z. (2010).Internet Use among College Student : Tool or Toy? Educational Review. 62(1) pp.85-96.

[19]. Fraenkel, J. R. \& Wallen, N. E. (2003) How to Design and Evaluate Research in Education, $5^{\text {th }}$ ed. Boston: McGraw Hill, pp 96-97,118-119

[20]. Hargittai, E. \& Hsieh, Y. P. (2010). Predictors and Consequences of Differentiated Practices on Social Network Sites. Information, Communication \& Society, 13(4), pp. 515-536.

[21]. Hong, F. Y., S. I. \& Hong, D. H. (2012), A Model of the Relationship Between Psychological Characteristics, Mobile Phone Addiction and use of Mobile Phones by Taiwanese University Female Students, Computers in Human Behaviour, 28, (6), pp. 2152-2159.

[22]. Hrastinski, S. (2009). A Theory of Online Learning as Online Participation. Computers \& Education, 52, 78-82. doi:10.1016/j.compedu.2008.06.009

[23]. Heafner, T. L., \& Friedman, A. M. (2008). Wikis and Constructivism in Secondary Social studies: Fostering a deeper understanding. Computers in the Schools, 25, 288-302.

[24]. doi:10.1080/0738056080237100

[25]. Jacobsen, W. C., \& Forste, R. (2011). The Wired Generation: Academic and Social Outcomes of Electronic Media Use Among University Students. Cyber Psychology Behaviour \& Social Networking 18,(5) pp.6, 275-285.

[26]. Junco, R. (2012a). The Relationship between Frequency of Facebook Use, participation in Facebook Activities, and Student Engagement. Computers \& Education, 58, 162-

[27]. 171. doi:10.1016/j.compedu.2011.08.004

[28]. Junco, R. (2012b). Too Much face and not Enough Books: The Relationship between Multiple Indices of Facebook Use and Academic Performance. Computers in Human Behavior, 28,187-198. doi:10.1016/j.chb.2011.08.026

[29]. Junco, R., Helbergert, G., \& Loken, E. (2011). The Effect of Twitter on college student engagement and grades. Journal of Computer Assisted Learning, 27, 119-132. doi:10.1111/j.1365-2729.2010.00387.x

[30]. Junco, R., Heibergert, G. \& Loken, E. (2010). The Effect of Twitter on College Students Engagement and Grades, Journal of Computer Assisted Learning, pp 1-14.

[31]. Kaitlin, C. (2010) Social Media Changing Social Interactions. Student Journal of Media Literacy Education, Issue 1, Vol. 1. pp. 1- 11 .

[32]. Karpinski, A, C. \& Duberstein, A. (2009). A Description of Facebook Use and Academic Performance among Undergraduate and Graduate Students. San Diego, California: American National Research Association. pp 1- 19.

[33]. Khan, U. (2009). Facebook Student Underachieve in Exams. Daily Telegraph, Retrieved on July, 2013, from http://www.telegraph.co.uk/educationnews/5145243/Faceb ook-students- underachieve-in-exams.html

[34]. Kuppuswamy, S., \& Narayan, P. (2010). The Impact of Social Networking Websites on the Education of Youth. International Journal of Virtual Communities and Social Networking (IJVCSN), 2(1), 67-79

[35]. Kist, W. (2008). I gave up MySpace for lent: New Teachers and Social Networking Sites.

[36]. Journal of Adolescent \& Adult Literacy. 52 (3) pp. 245.247

[37]. Kubey, R., Lavin, M. \& Barrows, J. (2001) Internet Use and Collegiate Academic Performance Decrements: Early Findings. J. Commum., 51 (92), pp. 366-382.

[38]. Kumekpor, T. K. B. (2002) Research Methods and Techniques of Social Research. Accra: Sonlife, pp 117-118

[39]. Lewis, S. (2008). Where Young Adults intend to get News in Five Years. Newspaper Research Journal 39 (4), pp $36-52$.

[40]. Lusk, B. (2010) Digital Natives and Social Media Behaviors: An Overview. The Prevention Research, Vol. 17, pp 3-6.

[41]. Martin, J.L., Yeung, K., (2006.) Persistence of Close Personal Ties Over a 12-year period.

[42]. Social Networks; 28, pp 331-362.

[43]. Mazman, S. G., \& Usluel, Y. K. (2010). Modeling Educational Usage of Facebook. Computers \&

Education, 
55, 444-453. doi:10.1016/j.compedu.2010.02.00

[44]. MehMood, S, \& Taswir, T, (2013) The Effect of Social Networking site on the Academic Performance on Students in College of Applied Sciences, Nizwa, Oman. International Journal of Arts and Commence. Vol. 2, No. 1 pp 111-123

[45]. Nalwa, K,\& Anan, A.P. (2003). Internet Addiction in Students: A Case of Concern.

[46]. CyberPsychology Behaviour, doi:10.1089/109493103322725441.06(6): pp. 653-656.

[47]. Pasek, J. \& Hargittai, E. (2009, May). Facebook and Academic Performance: Reconciling a Media Sensation with Data. First Monday, 14 (4-5). pp 1- 25

[48]. Pempek, T. A., Yermolayeva, Y. A., \& Calvert, S. L. (2009). College Students' Social Networking Experiences on Facebook. Journal of Applied Development psychology, 30(3), pp. 227-238. doi:10.1016/j.appdev.2008.12.010

[49]. Quan-Haase, A., \& Young, A. L. (2010). Uses and Gratifications of Social Media: A Comparison of Facebook and Instant Messaging. Bulletin of Science, Technology \& Society, 30(5), pp. $350-361$. doi:10.1177/0270467610380009

[50]. Rithika M. and Sara S (2013) Impact of Social Media on Student's Academic

[51]. Performance International Journal of Logistics \&Supply Chain Management Perspective Volume 2, Number 4

[52]. Sanchez-Martinez, M. \& Otero, A. (2009), Factors Associated with Cell Phone Use in Adolescents in the Community of Madrid (Spain). Cyberpsychology, Behaviour, 12, pp. 131-137.

[53]. San Miguel, R. (2010) Study on Facebook and Grades Becomes Learning Experience for Researcher. TechNewsWorld.

[54]. http://www.technewsworld.com/rsstory/66805.html?wlc=1286985671\&wlc=1287195471 Retrieved 20/08/13

[55]. Shoshani, Y., \& Rose Braun, H. (2007). The Use of the Internet Environment for Enhancing creativity. Educational Media International, 44(1), 17-32. doi:10.1080/0952398060092280

[56]. Schill, R. (2011). Social Networking Teens More Likely to Drink, Use Drugs, Study Finds. http://jijie.org/teenson-facebook-more-likely-drink-or-Retrieved 16/08/13

[57]. Schneider N. (2010) Facebook, Other Social Network Sites Could Lead to Lower Grades for Students. http://www.associatedcontent.com/article.1650000/facebook_other_social_network_sites.html? cat=4. Retrieved 20/08/13

[58]. Sheldon, P. (2008). Students Favourite: Facebook and Motives for its use. Southwestern Mass Communication Journal, 23(2), pp. 39-53.

[59]. University of New Hampshire (2010) Student Grades Not Affected by Social Networking http://www.newswise.com/articles/student-grades-not-affected-by-social-networking-_new-research-finds. Retrieved 20/08/13

[60]. Wang, Q., Chen, W. \& Liang, Y. (2011), The Effects of Social media on College Students. The Alan Shawn Feinstein Graduate School. Providence: Johnson \& Wales University.

[61]. Watson, J. (2001). How to Determining a Sample Size: Tipsheet (60) University Park, PA Penn State Cooperative Extension. Available at: http://www.extention.psu/edu/evaluation/pdf/Ts60.pdf.accessed 2012 ,

[62]. Yen, C., T. Tang, T. Yen, J., Lin H., Huarng, C. \& Liu, S. (2009). Symptoms of Problematic Cellular Phone use, Functional Impairment and its Association with Depression among Adolescents in Southern Taiwan. Journal of Adolescence, 32, pp. 863-873 